\title{
SHORELINE CHANGES ANALYSIS IN KUWARU COASTAL AREA, YOGYAKARTA, INDONESIA: AN APPLICATION OF THE DIGITAL SHORELINE ANALYSIS SYSTEM (DSAS)
}

\author{
BACHTIAR W. MUTAQIN \\ Faculty of Geography, Universitas Gadjah Mada, Indonesia. \\ Laboratoire de Géographie Physique UMR 8591, Université Paris 1 Panthéon Sorbonne, France.
}

\begin{abstract}
In the last 20 years, Kuwaru coastal area has been under constant threat from both physical and nonphysical processes. Such threat is exacerbated by the fact that this coastal area is mainly composed of loose sediment materials that are easily eroded and re-deposited as a response to disturbance. One of the threats is shoreline change. This research aims to analyze the shoreline change in Kuwaru coastal area with the aid of the Digital Shoreline Analysis System. Shoreline changes in the coastal area affects tourism and fishery activities, causes loss of land, and damages infrastructures, all of which mark the urgency of shoreline change analysis. Shoreline change is identified with an interdisciplinary approach, i.e. the integration of remote sensing technology and Geographic Information Systems (GIS). The topographic maps published in 1995 and the multi-temporal satellite imagery in 2006-2015 are used as initial information in acquiring necessary shoreline data. Shoreline change is analyzed using the End Point Rate (EPR) technique. Shoreline data in 1995 is used as the baseline in analyzing the rate of shoreline change. Furthermore, transects spaced at 50-meter intervals along the shoreline stretch landward and perpendicularly to the baseline. EPR results in either positive or negative values that indicate accretion or erosion, respectively. This research finds that the shoreline of Kuwaru coastal area has changed significantly since 1995 . In general, from 1995 to 2015, the shoreline shifted by more than 50 meters landward. Extreme weather during the East Monsoon is one of the many factors that induce destructive waves in the research area. Sea waves of up to 5 meters in height hit the southern part of the research area from the southeast. Consequently, coastal mitigation efforts, which factor in the dynamics of coastal processes, have to be implemented immediately through structural mitigation or non-structural mitigation.
\end{abstract}

Keywords: coastal, DSAS, dynamics, GIS, Kuwaru, processes, shoreline, Yogyakarta.

\section{INTRODUCTION}

In the last 15 years, coastal zone management in Indonesia has become an important subject in governance and national development policy. As an archipelagic state with a 99,093-km stretch of shoreline and 13,466 registered islands [1] as well as various problems occurring in its coastal area, Indonesia is in need of good coastal area management that particularly aims to ensure positive impact on the coastal community and on regional development. Research and studies pertaining to the Indonesian coastal area, including erosion, sedimentation, shoreline change, inundation, deflation, land subsidence, increasing water salinity, tsunami, and landuse change, have been receiving more attention from many scientists [2-9].

Shoreline change, as one of the most frequent natural hazards and the most widely researched coastal issues in the world, poses a serious threat to coastal environment, human life, and property [10-12]. It potentially generates more severe impact on the environment and human life especially due to the complexity and dynamics of environmental and social processes in an area. Therefore, shoreline change analysis has a significant role in coastal protection planning and risk and disaster management, e.g. through numerical method calibration and verification, sea-level rise assessment, and hazard zone development, as well as the policy-making process of coastal area development. 

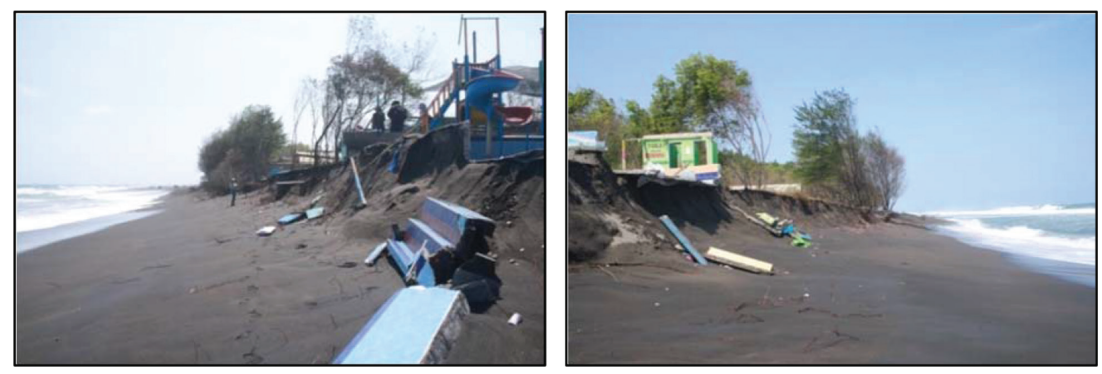

Figure 1: Impact of coastal erosion in Kuwaru.

Remote sensing, as compared to conventional survey techniques, is applicable for monitoring shoreline change in coastal area effectively, because of its high accuracy, more efficiency, and cost-effectiveness [13-17]. Meanwhile, Geographic Information Systems (GIS) technology enables users to create high-quality maps as well as visualize and simplify large and complex data. Research from various disciplines has been applying remote sensing data and GIS technology in coastal studies, especially in analyzing shoreline changes in Indonesia. For example, satellite imagery with high spatial and temporal resolutions is applied in analyzing shoreline changes caused by the 2004 Tsunami in Banda Aceh and its surrounding areas [18-19]. The combination of demographic, geomorphological, geological, and shoreline change data obtained from remote sensing accommodates a representative resilience assessment in Seribu Islands, Jakarta [20]. In addition, shoreline data, obtained using remote sensing technology, can be used as an input for modeling tsunami inundation [21] and identifying the impacts of climate change and sea level rise-induced environmental change [22].

This research aims to analyze the shoreline change in Kuwaru coastal area with a freely available software application, Digital Shoreline Analysis System (DSAS). Shoreline change in the research area affects tourism and fishery activities, causes loss of land, and damages infrastructures [23] (Fig. 1), all of which mark the urgency of shoreline change analysis. Loss of allocated land for tourism and fishery activities in Kuwaru (up to 1.5 ha) significantly reduces the number of tourists to $46 \%$ [24] and fresh-caught fish transactions, which lead to economic problems for the local people. As a result, the local people resort to different occupations and convert their farmlands to fishponds.

\section{RESEARCH AREA}

This research focuses on Kuwaru coastal area, which is located at the southern part of the Special Region of Yogyakarta that faces the Indian Ocean (Fig. 2). Based on the geological map issued by the Geological Agency of Indonesia, the research area is composed mainly of alluvium material transported from Merapi volcano by the Progo River, which is located $1.5 \mathrm{~km}$ from the west side of the research area.

Kuwaru coastal area is one of the famous tourist attractions in Bantul Regency. During 2011-2013, a number of 673,790 tourists visited the area, resulting in a total income of IDR 1,454,247,750 (EUR 100,000) from entrance ticket sale alone (Table 1) [24]. On the other hand, in the last 20 years, Kuwaru coastal area has been under constant threat of both physical and non-physical processes. This threat, induced by the hydrodynamic factors of the Indian Ocean (e.g. wind, waves, and currents), can easily move the sediment materials in Kuwaru because these materials are composed mainly of loose sediment that is easily eroded and redeposited as a response to disturbance [25]. 


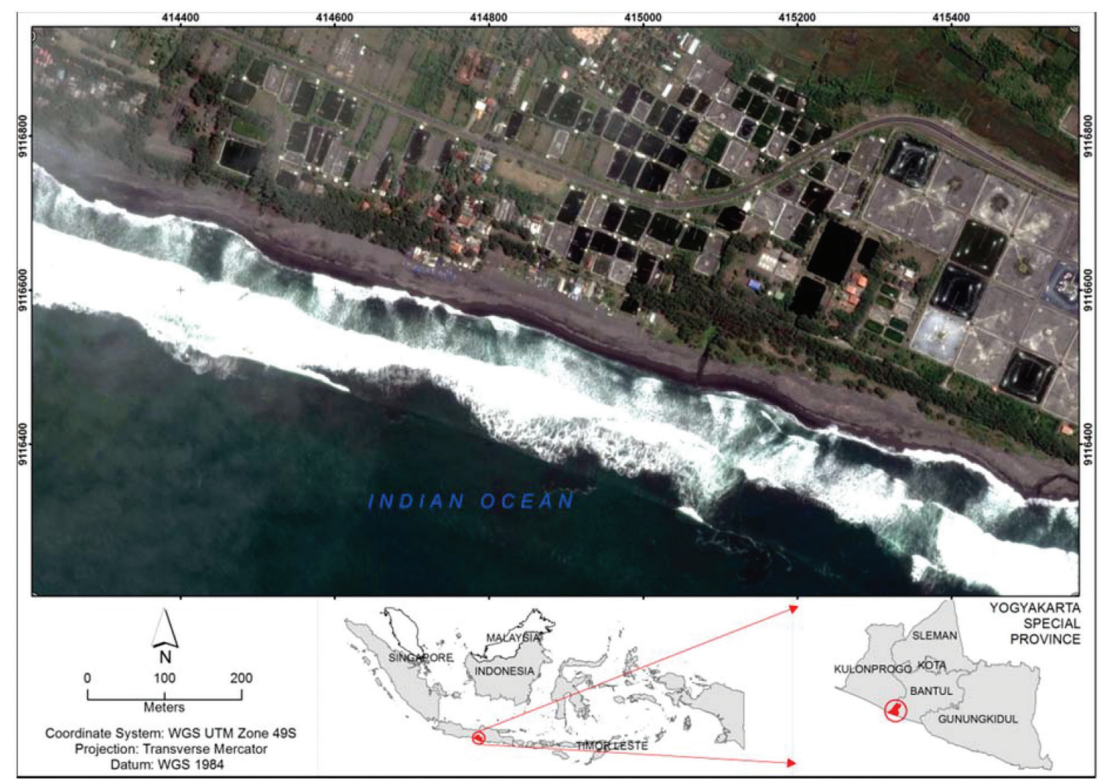

Figure 2: Kuwaru coastal area.

Table 1: Number of tourists and income in Kuwaru (2011-2013).

\begin{tabular}{lrrr}
\hline & 2011 & 2012 & \multicolumn{1}{c}{2013} \\
\hline Number of tourists & 268,435 & 259,513 & 145,842 \\
Income (IDR) & $578,313,500$ & $519,026,000$ & $356,908,250$ \\
in Euro (€) & 39,884 & 35,795 & 24,614 \\
\hline
\end{tabular}

\section{DATA AND METHODS}

\subsection{Shoreline data}

Shoreline data is initially obtained from the 1:25,000 topographic maps issued by the Indonesian Geospatial Information Agency in 1995 and the multi-temporal satellite imagery (2006-2015) downloaded from Google Earth archive (Digital Globe imagery). The satellite images are downloaded by considering image retrieval date. The images have to be retrieved in the days of the same season in order to anticipate tidal variation error between the images during shoreline extraction process. In this research, the image retrieval date is of the days in the dry season in Indonesia that normally occurs in May-October. The research uses satellite images retrieved from six different days, viz.: August 11, 2006; May 31, 2009; August 24, 2012; August 2, 2013; August 19, 2014; and June 13, 2015. The image rectification is implemented using WGS84 datum and zone 49S in UTM projection.

Shoreline change is identified with an interdisciplinary approach, i.e. the integration of remote sensing technology and GIS. The multi-temporal shoreline positions were detected using histogram equalization, visual interpretation, and manual delineation methods using 


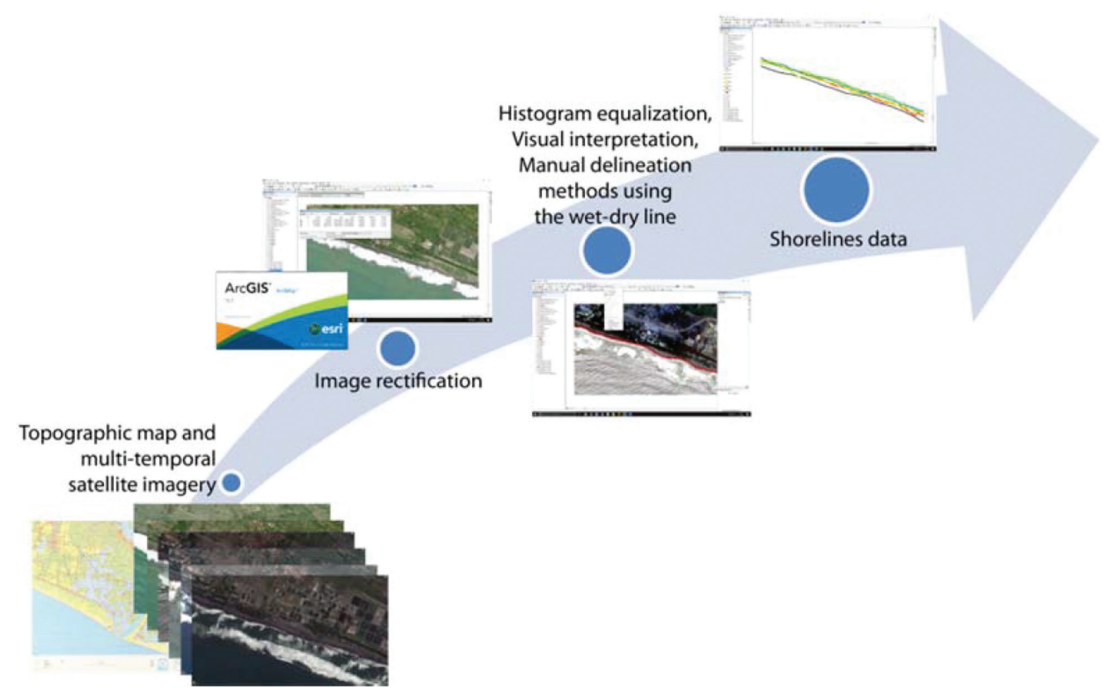

Figure 3: Shorelines extraction process.

the wet-dry line as an estimation to map shoreline positions. In order to evaluate the accuracy of extracted shoreline as well as to obtain the best results, ground surveys with GPS were conducted on August 27, 2013 and June 6, 2014 (Fig. 3).

\subsection{Shoreline changes analysis}

Shoreline change is analyzed statistically using DSAS extension in ArcGIS software. DSAS has many statistical options for analyzing shoreline change data. These options are, for example, Shoreline Change Envelope (SCE), Net Shoreline Movement (NSM), End Point Rate (EPR), and Linear Regression (LRR) [26].

SCE and NSM provide a shoreline distance at each transect; however, their results do not include information on the rate at which the shoreline changes. SCE calculates the greatest distance between all shorelines without factoring in the year of the shoreline, while NSM represents a total distance between the oldest and the most recent shoreline, i.e. 2006 and 2015, respectively.

EPR and LRR provide the rate of shoreline change at each transect. EPR is the distance of shoreline shift divided by the time elapsed between the 2006 and 2015 shorelines. Meanwhile, LRR is determined by fitting a least squares regression line to all shoreline points for a particular transect. Even though LRR uses all available shorelines and provides a statistically robust analysis, it is susceptible to outlier effects [27,28]. Therefore, this research uses EPR to analyze the rate of shoreline change. In NSM and EPR, positive values refer to accretion, while negative values indicate erosion.

In this research, the 1995 shoreline data is used as a baseline because the shoreline data from the existing high-resolution imagery (2006-2015) did not meet the requirements for the baseline, i.e. the baseline should be established adjacent to the series of shoreline positions and cannot place entirely onshore or offshore with respect to the other shorelines. Furthermore, 29 transects spaced at 50-meter intervals along the shoreline stretch 100 meters landward and perpendicularly to the baseline. These transects are the starting points of the 
statistical calculation from the baseline to each shoreline. Every crossing point between the transects and the shorelines is analyzed in order to generate the distance and rate of shoreline change in Kuwaru coastal area.

\section{RESULTS AND DISCUSSION}

\subsection{Results}

\subsubsection{Shoreline data}

The interpretation of the results of the multi-temporal satellite imagery show that the shoreline change in Kuwaru coastal area is very dynamic (Fig. 4). As one of the most dynamic process in coastal areas, shoreline change may occur as a short-term event caused by hydrodynamic factors or a long-term event like tectonic activities [2, 7, 8], and [10, 11].

\subsubsection{The distance of shoreline change}

The distance of shoreline change is measured using SCE and NSM, while the rate of shoreline change is calculated using EPR. The result of SCE (Fig. 5) shows that the greatest

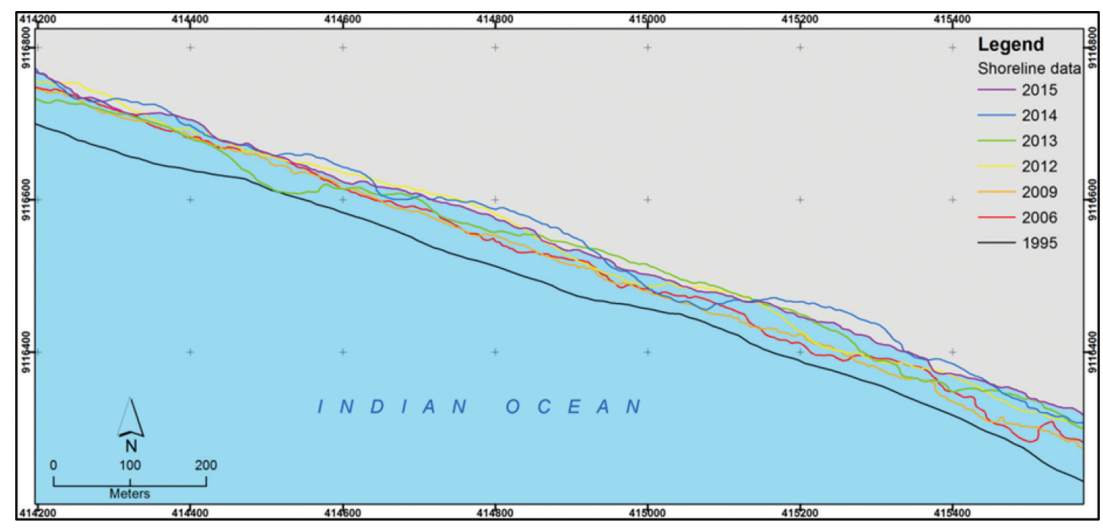

Figure 4: Shoreline change in Kuwaru coastal area.

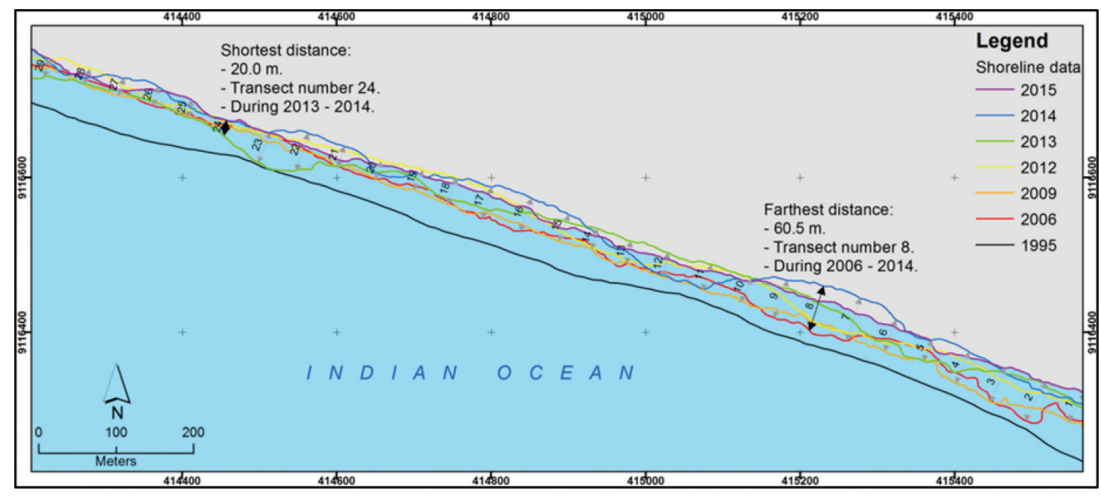

Figure 5: The result of SCE in Kuwaru coastal area. 


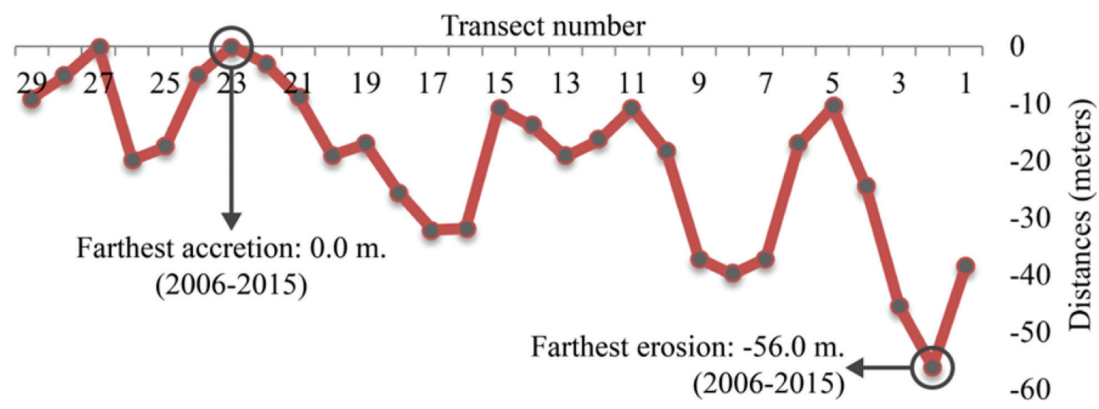

Figure 6: The result of NSM in 2006-2015.

shoreline change in 2006-2015 was $60.5 \mathrm{~m}$, which represents either accretion or erosion. Even though SCE always results in positive values, the resultant shoreline change does not always refer to accretion. The farthest distance of shoreline change in the research area is found at transect number 8 . However, the average distance from the farthest and the closest shoreline shift to the 1995 shoreline is $36.5 \mathrm{~m}$.

The distance between the 2006 and 2015 shorelines, as measured using NSM, is presented in Fig. 6. The result of NSM shows that the farthest accretion and erosion in 2006-2015 are $0.0 \mathrm{~m}$ and $-56.0 \mathrm{~m}$, respectively, and the average distance of shoreline change is $-20.0 \mathrm{~m}$. In contrast to SCE, NSM results in either positive or negative values that refer to accretion or erosion, respectively. The result of NSM shows a negative value for the average distance of shoreline change, which represents the likeliness of erosion instead of accretion as the trend of shoreline change in Kuwaru coastal area.

\subsubsection{The rate of shoreline change}

The rate of shoreline change (meter/year) is obtained technically by dividing the distance of shoreline displacement (meters) by the time elapsed between the years of satellite images used in the analysis (years) [26]. Table 2 shows the rate of shoreline change, as measured using EPR, in Kuwaru coastal area in 2006-2015.

A zero lowest rate in 2006-2015, found at transect number 23, does not represent any shoreline movement because the result of SCE at the same transect shows that the greatest distance between the shorelines is $41.0 \mathrm{~m}$. The zero lowest rate is caused by one variable used in EPR, i.e. the very short distance of shoreline movement $(<0.5 \mathrm{~m})$ at transect number 23 (Fig. 7). In general, the average rate of shoreline change is negative $(-2.3 \mathrm{~m} / \mathrm{year})$, which corroborates the result of NSM that states erosion as a more likely trend of shoreline change in the research area in 2006-2015.

Table 2: The rate of shoreline change in 2006-2015 obtained from EPR (m/year).

\begin{tabular}{lll}
\hline Highest rate & Lowest rate & Average rate \\
\hline-6.3 & 0.0 & -2.3 \\
\hline
\end{tabular}




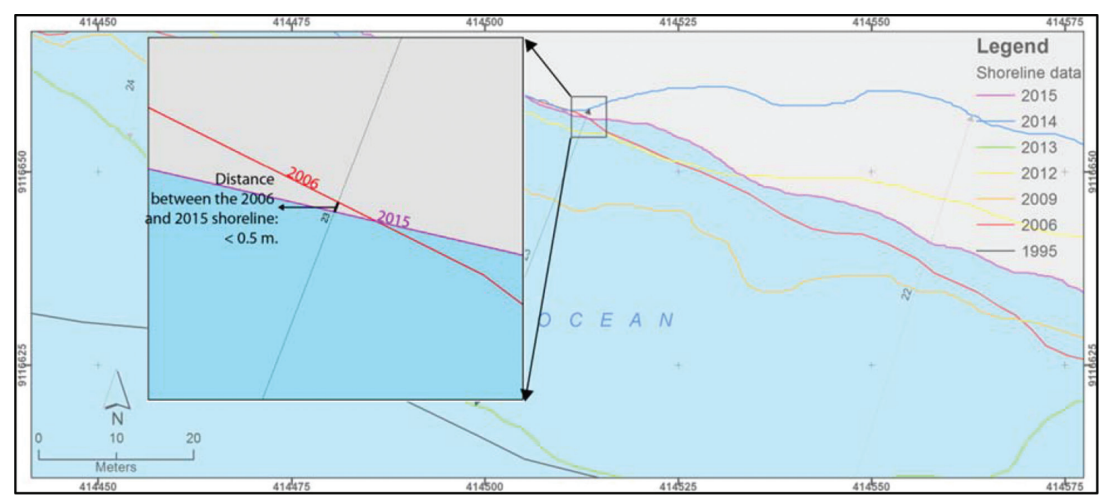

Figure 7: The lowest rate (i.e. $0.0 \mathrm{~m} /$ year) in 2006-2015, found at transect number 23.

\subsection{Discussions}

Coastal dynamics is a natural process that occurs as a result of seasonal weather variability and hydro-oceanographic factors. However, at certain times, it has a destructive nature that potentially damages public facilities and infrastructures and leads to environmental damage. Aside from tsunami, shoreline change is one of the major issues on the southern coast of Java Island in Indonesia. In the last 20 years, shoreline change in Kuwaru coastal area has been a concern of the local government since it caused severe impacts on the environment and human activity, and from an economic aspect.

Based on the analysis results, during the period 2006-2015 coastal erosion has occurred in Kuwaru with an average shoreline distance of $-20.0 \mathrm{~m}$ and at an average rate of $-2.3 \mathrm{~m} /$ year. The coastal erosion is influenced by several factors, some of which are wave activity, sediment material, coastal protection, and landuse. The predominant factor of the coastal dynamics in Kuwaru is wave activity.

Wave is one of the forces that cause sediment erosion and transport in coastal areas. Waves that arrive on a coast are generated by winds that transfer their energy into the water. Wind measurements on August 27, 2013 and June 2-6, 2014 present a temporal variation of wind speeds. For example, the wind speed on June 5, 2014 was $5.1 \mathrm{~m} / \mathrm{s}$ in the morning, which then increased linearly in the afternoon $(8.6 \mathrm{~m} / \mathrm{s})$ and in the evening $(12.4 \mathrm{~m} / \mathrm{s})$. In dry season, the waves in Kuwaru are normally classified as swells and constructive waves; however, in extreme weather (e.g. storms), the energy of wind and wave increases [29]. Consequently, a destructive wave is formed. Destructive waves have a weak swash but strong backwash that is powerful enough to remove sediment material at the coast. The coast is eroded away over time.

Several previous extreme conditions that led to destructive waves in Kuwaru coastal area are presented in Table 3 [30-34] and Fig. 8. There were no casualties; however, various losses and damages were caused to buildings, coastal vegetation, and public facilities. In July 2011, the access road to the beach eroded up to $20 \mathrm{~m}$ and the distance between the fish auction place and the beach was diminished by up to $150 \mathrm{~m}$. The destructive wave that occurred in April 2012 with a height of 5-7 m resulted in a number of inundated stalls and many fishermen securing their boats and nets. In September 2013 and June 2016, due to the high waves Disaster Relief Agency of Bantul urged people to evacuate and avoid activities near the beach. 
Table 3: Examples of previous extreme conditions in Kuwaru coastal area.

\begin{tabular}{|c|c|c|}
\hline Date & Wave height (m) & Loss and damage \\
\hline July 2011 & $4-5$ & $\begin{array}{l}\text { Damaged roads, collapsed lighthouse; } \\
\text { Command post of Search and Rescue and turtle } \\
\text { breeding sites were swept away. }\end{array}$ \\
\hline $\begin{array}{l}\text { April 4-6 and } \\
\text { April 20, } 2012\end{array}$ & $5-7$ & A number of inundated stalls, but no damage. \\
\hline $\begin{array}{l}\text { September } \\
10-18,2013\end{array}$ & $4-5$ & $\begin{array}{l}53 \text { stalls were swept away; } 25 \text { stalls were } \\
\text { heavily damaged. }\end{array}$ \\
\hline June 5-8, 2016 & \pm 7 & Several number of food stalls were damaged. \\
\hline
\end{tabular}
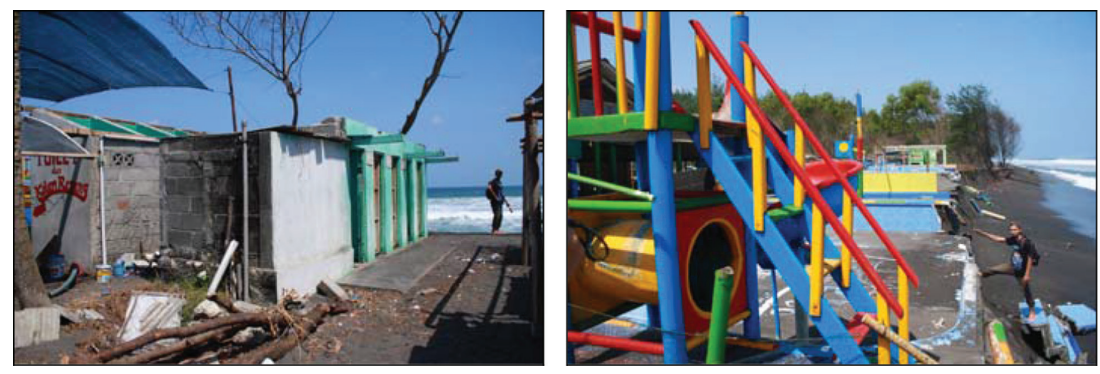

Figure 8: Heavily damaged stalls in September 2013.

Casuarina equisetifolia (Fig. 9) that has been planted in Kuwaru for coastal defense since 1994 has not had significant impacts on erosion prevention. C. equisetifolia trees were planted in Kuwaru in 1994 by Faculty of Forestry Universitas Gadjah Mada (FoF-UGM); in 2000 by FoF-UGM, PT INDOCOR, and local peoples; and in 2001 by Indonesian Ministry of Forestry. Even though these trees are very useful as shelters as well as wind barriers, they are not resistant to coastal erosion in the research area. The local people estimated that more than 2,000 trees have been swept away since 2012 [35] resulting in a decreased number of tourists in Kuwaru. Based on interviews with the local people who manage parking area in this place of tourist attraction, the total revenue from parking services has decreased significantly since 2012. Before the occurrence of coastal erosion, the same revenue was up to IDR $8,000,000$ per day (EUR 550). In 2013, the highest revenue was IDR 2,000,000 per day (EUR 138) [35].
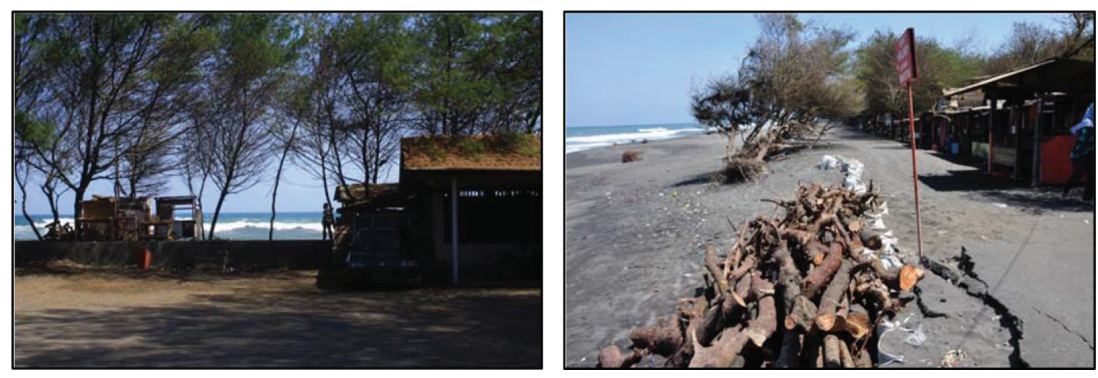

Figure 9: The condition of Casuarina equisetifolia in Kuwaru. 
The local government provides a new location for stalls that are threatened and damaged by coastal erosion. However, the stall owners refuse to relocate and prefer to stay in the affected area rather than leave to the new location. Interviews to stall owners reveal that this preference is provoked by the inconvenience of moving to another place especially because the new location is far from the beach. They associate the far location from tourist attraction with a decreased number of buyers.

Furthermore, they perceive coastal erosion as a non-daily phenomenon that only occurs in extreme weather [36]. Coastal erosion reduces the income of the stall owners and causes the local people who no longer own a stall or a building in Kuwaru to change their livelihood and convert their farmland to fishpond (Fig. 10).

Based on the trend of shoreline change in Kuwaru and its impact on the environment and human life, prevention and mitigation measures generated from information on the existing disaster, as well as integrated coastal planning and management have to be implemented immediately through structural mitigation or non-structural mitigation. Furthermore, public awareness and community participation also play an important role in reducing the risk of

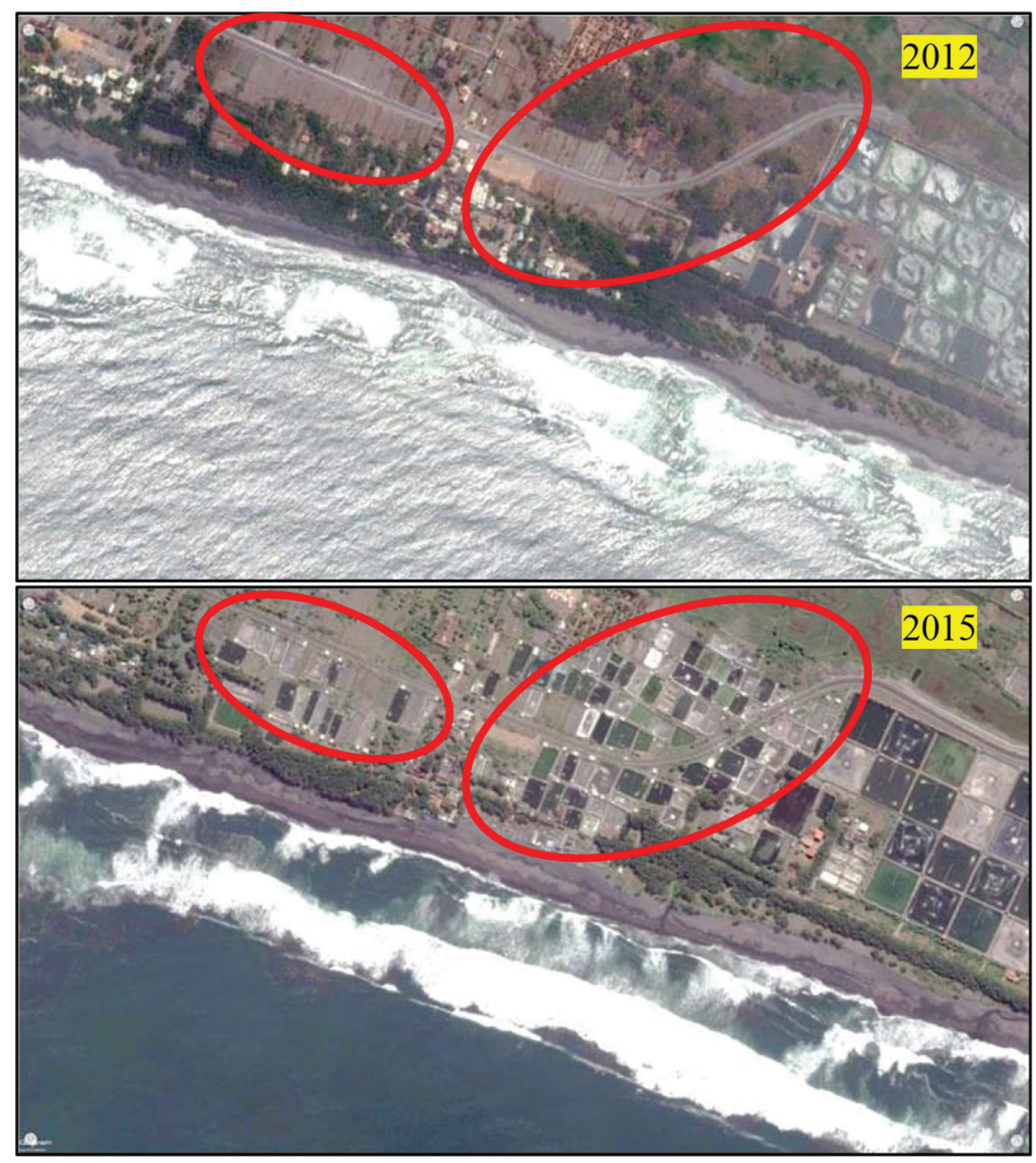

Figure 10: The number of fishponds (red circle) has increased significantly since 2012. 
coastal erosion in Kuwaru. Accurate information, training, and public dissemination will be helpful in increasing community awareness of disaster.

\section{CONCLUSIONS}

Kuwaru has very dynamic coastal areas whose average distance and rate of shoreline change in the last 9 years (2006-2015) are $-20.0 \mathrm{~m}$ and $-2.3 \mathrm{~m} /$ year, respectively. Due to the severe impacts of shoreline change, coastal mitigation efforts that factor in the dynamics of coastal processes have to be implemented immediately through structural mitigation, non-structural mitigation, and the improvement of public awareness and community participation in the research area.

\section{REFERENCES}

[1] Pentingnya Informasi Geospasial untuk Menata Laut Indonesia. Geospatial Information Agency, Cibinong, available at www.bakosurtanal.go.id/berita-surta/show/pentingnyainformasi-geospasial-untuk-menata-laut-indonesia (accessed 26 March 2015).

[2] Marfai, M.A., King, L., Singh, L.P., Mardiatno, D., Sartohadi, J., Hadmoko, D.S. \& Dewi, A., Natural hazard in central Java Indonesia: an overview. Environmental Geology, 56(2), pp. 335-351, 2008. https://doi.org/10.1007/s00254-007-1169-9

[3] Sartohadi, J., Marfai, M.A. \& Mardiatno, D., Coastal zone management due to abrasion along the coastal area of Tegal, Central Java Indonesia. Proceeding of International Coastal Conference, Nagoya, Japan, pp. 37-44, 2009.

[4] Mardiatno, D., Marfai, M.A. \& Sartohadi, J., Multi-risks of disasters in Cilacap City, Indonesia. Proceeding International Coastal Conference, Nagoya, Japan, pp. 6-14, 2009.

[5] Sunarto, Marfai, M.A., Mardiatno, D. \& Rahayu, L., Multi disaster risk reduction strategy for mitigation and adaptation case study of the North Zone Central Java. Journal of Disaster Indonesia, 3, pp. 619-634, 2010.

[6] Mardiatno, D. \& Mutaqin, B.W., Spatio-temporal modelling of population distribution for the tsunami risk assessment in Pacitan, Indonesia. The Investigation Report of 2004 Northern Sumatra Earthquake (Additional Vol.), pp. 100-108, 2011.

[7] Mutaqin, B.W., Trihatmoko, E., Fitriani, A.K.N. \& Jumari., Studi Pendahuluan Dinamika Wilayah Kepesisiran di Muara Delta Porong setelah Erupsi Mud-Volcano Sidoarjo Tahun 2006. Prosiding Seminar Nasional Pendayagunaan Informasi Geospasial untuk Optimalisasi Otonomi Daerah, pp. 27-31, 2013.

[8] Mutaqin, B.W., Nugraha, H., Puspitorukmi, A., Lavigne, F., Hartono, H. \& Marfai, M.A., Shoreline dynamics and various associated processes in the Batang Coastal Area, Indonesia. EGU General Assembly, Vienna, Austria, 2015.

[9] Boillot-Airaksinen, K., Lavigne, F., Mutaqin, B.W., Sudrajat, Y., De Belizal, E., Komorowski, J.C., Virmoux, C., Giet, C., Sutarman, Nyanjang, Hiden, Syamsuddin, Hadmoko, D.S. \& Handayani, L., The geomorphic impacts of the AD 1257 eruption of Samalas Volcano (Indonesia) on the western coastline of Lombok Island. Cities on Volcanoes 9, Puerto Varas, Chile, 2016.

[10] Bagli, S. \& Soille, P., Morphological automatic extraction of Pan-European coastline from Landsat ETM+ images. Proceeding International Symposium on GIS and Computer Cartography for Coastal Zone Management, Genova, 2003. 
[11] Mills, J.P., Buckley, S.J., Mitchell, H.L., Clarke, P.J. \& Edwards, S.J., A geomatics data integration technique for coastal change monitoring. Earth Surface Processes and Landforms, 30, pp. 651-664, 2005. https://doi.org/10.1002/esp.1165

[12] Lavigne, F., Boillot-Airaksinen, K., Mutaqin, B.W., Sudrajat Y., Hiden, Syamsuddin, Komorowski, J.C., Sutarman, Nyanjang, Giet, C., De Belizal, E., Virmoux, C., Wassmer, P., Pratomo, I., Hadmoko, D.S., Kusnadin, Handayani, L. \& Hananto, N., How to Reconstruct the landscape of Lombok Island (Indonesia) during the Kingdom of Pamatan Buried by the AD 1257 PDC Deposits of Samalas Volcano? Cities on Volcanoes 9, Puerto Varas, Chile, 2016.

[13] Boak, E.H. \& Turner, I.L., The Shoreline detection-definition problem: a review. Journal of Coastal Research, 21(4): pp. 688-703, 2005.

https://doi.org/10.1002/esp.1165

[14] Muslim, A.M., Foody, G.M. \& Atkinson, P.M., Localized soft classification for superresolution mapping of the shoreline. International Journal of Remote Sensing. 27, pp. 2271-2285, 2006.

https://doi.org/10.1080/01431160500396741

[15] Addo, K.A., Walkden, M. \& Mills, J.P., Detection, measurement and prediction of shoreline recession in Accra, Ghana. ISPRS Journal Photogrammetry and Remote Sensing. 63, pp. 543-558, 2008.

https://doi.org/10.1016/j.isprsjprs.2008.04.001

[16] Lukas, M.C., Neglected treasures: linking historical cartography with environmental changes in Java, Indonesia. Cartographica, 50(3), pp. 141-162, 2015.

https://doi.org/10.3138/cart.50.3.2891

[17] Dewi, R.S., Bijker, W., Stein, A. \& Marfai, M.A., Fuzzy Classification for Shoreline Change Monitoring in a Part of the Northern Coastal Area of Java, Indonesia. Remote Sens, 8(3), p. 190, 2016. https://doi.org/10.3390/rs8030190

[18] Yang, M.D., Su, T.C., Hsu, C.H., Chang, K.C. \& Wu, A.M., Mapping of the 26 December 2004 tsunami disaster by using FORMOSAT2 images. International Journal of Remote Sensing, 28(13-14), pp. 3071-3091, 2007. https://doi.org/10.1080/01431160601094500

[19] Monecke, K., Templeton, C.K., Finger, W., Houston, B., Luthi, S., McAdoo, B.G., Meilianda, E., Storms, J.E.A., Walstra, D., Amna, R., Hood, N., Karmanocky III, F.J., Nurjanah, R.I. \& Sudrajat, S.U., Beach ridge patterns in West Aceh, Indonesia, and their response to large earthquakes along the northern Sunda trench. Quaternary Science Reviews, 113, pp. 159-170, 2015. https://doi.org/10.1016/j.quascirev.2014.10.014

[20] Farhan, A.R. \& Lim, S., Resilience assessment on coastline changes and urban settlements: a case study in Seribu Islands, Indonesia. Ocean and Coastal Management, 54, pp. 391-400, 2010. https://doi.org/10.1016/j.ocecoaman.2010.12.003

[21] Li, L., Huang, Z., Qiu, Q., Natawidjaya, D.H. \& Sieh, K., Tsunami-induced coastal change: scenario studies for Painan, West Sumatra, Indonesia. Earth Planets Space, 64, pp. 799-816, 2012.

https://doi.org/10.5047/eps.2011.08.002 
[22] Marfai, M.A., Impact of sea level rise to coastal ecology: a case study on the northern part of Java Island, Indonesia. Quaestiones Geographicae, 33(1), 2014. Bogucki Wydawnictwo Naukowe, Poznań, pp. 107-114, 2012.

[23] Mutaqin, B.W., Mardiatno, D., Santosa, L.W. \& Marfai, M.A., Sunarto, Pemanfaatan Informasi Geospasial untuk Identifikasi Perubahan Garis Pantai di Kawasan Kepesisiran Kuwaru, Yogyakarta. Prosiding Pertemuan Ilmiah Tahunan (PIT) Ikatan Geografi Indonesia (IGI), XVI, pp. 275-279, 2013.

[24] Retribusi Obyek Wisata (realisasi 2011-2013). Dinas Kebudayaan dan Pariwisata, Pemerintah Kab. Bantul, Yogyakarta, available at http://disbudpar.bantulkab.go.id/data/ list/1/2/5-retribusi-obyek-wisata-realisasi (accessed 13 June 2015).

[25] Zeverbergen L.W., Lagasse P.F. \& Edge B.L., Tydal Hydrology, Hydraulics and Scour at Bridges, 1st edn., Federal Highway Administration, Washington, DC, 2014.

[26] Thieler, E.R., Himmelstoss, E.A., Zichichi, J.L. \& Ergul, A., Digital Shoreline Analysis System (DSAS) version 4.0 - An ArcGIS extension for calculating shoreline change, U.S. Geological Survey Open-File Report 2008-1278. *current version 4.3, 2009.

[27] Dolan, R., Fenster, M.S. \& Holme, S.J., Temporal analysis of shoreline recession and accretion. Journal of Coastal Research, 7, pp. 723-744, 1991.

[28] Brooks, S.M. \& Spencer, T., Temporal and spatial variations in recession rates and sediment release from soft rock cliffs, Suffolk coast, UK. Geomorphology, 124(1-2), pp. 26-41, 2010.

https://doi.org/10.1016/j.geomorph.2010.08.005

[29] Mutaqin, B.W., Agustina, N. \& Permatasari, C.W., Characteristics of waves in kuwaru waters during the East Monsoon. IJJSS 2014: The 6th Indonesia Japan Joint Scientific Symposium, Indonesia, 2014.

[30] Kuwaru Alami Abrasi Parah, Surat Kabar Harian Nasional-KOMPAS, available at http://nasional.kompas.com/read/2011/08/08/03324532/Kuwaru.Alami.Abrasi.Parah (accessed 28 August 2013).

[31] Pantai Kuwaru Diterjang Ombak 7 Meter, Surat Kabar Harian Jogja, available at www. harianjogja.com/baca/2012/04/20/pantai-kuwaru-diterjang-ombak-7-meter-179712 (accessed 28 August 2013).

[32] Data Kejadian Bencana Abrasi, Badan Nasional Penanggulangan Bencana, Jakarta, available at http://geospasial.bnpb.go.id/pantauanbencana/data/dataabrasiall.php (accessed 7 June 2014).

[33] Abrasi Pantai Kuwaru, Warung Pedagang Rusak, Surat Kabar Harian Tribun Jogja, available at http://jogja.tribunnews.com/2016/06/06/abrasi-pantai-kuwaru-warungpedagang-rusak (accessed 15 June 2016).

[34] Pantai Wisata di Yogya Diterjang Ombak Besar, Tempo Nasional, available at https:// nasional.tempo.co/read/news/2016/06/08/058777965/pantai-wsata-di-yogya-diterjangombak-besar (accessed 15 June 2016).

[35] Rubiyanto. Personal communication, Locals in Kuwaru, Bantul District, Yogyakarta Special Province, Indonesia, 23 September 2013.

[36] Turmiati, Sujono, and E. Prakoso. Personal communication, Stall owners in Kuwaru, Bantul District, Yogyakarta Special Province, Indonesia, 23 September 2013. 